\title{
Planktonic bacteria in estuaries and coastal waters of northern Massachusetts: spatial and temporal distribution
}

\author{
Richard T. Wright and Richard B. Coffin*
}

Gordon College, Wenham, Massachusetts 01984, USA

\begin{abstract}
The Essex, Parker and Ipswich River estuaries are salt marsh estuaries that empty into Ipswich Bay in northern Massachusetts, USA. The Essex estuary was the subject of a year-long study of planktonic bacteria numbers and heterotrophic activity, with monthly sampling of the entire range of water within the estuary. Both numbers and activity were fractionated into 4 sizes using Nuclepore filters. The Ipswich and Parker River estuaries were sampled along with the Essex on 5 occasions for comparison purposes. In winter, counts and activity were uniformly low throughout the Essex estuary. During spring, there gradually developed a peak of bacteria in mid-estuarine waters which was sustained through the summer and subsided in fall. The seasonal range in these waters was 10 -fold $(0.7$ to $7.0 \times 10^{6} \mathrm{ml}^{-1}$ ), while the range was lower in coastal waters (4-fold). This peak also occurred prominently in the Parker, but was modified in the Ipswich because of physical factors. Maximum numbers and activity were consistently found in the 0.4 to $0.6 \mu \mathrm{m}$ fraction. Bacteria counts were strongly related to temperature, with the greatest dependence in mid-estuarine waters. Heterotrophic activity was logarithmically related to temperature and followed the same pattern as counts. The increment of bacteria with linear distance upriver to where the maximum is found was very similar in the 3 estuaries. It is suggested that this is a function of the availability of substrate as influenced by tidal mixing, and involves considering the bacteria as dynamic constituents of estuarine and coastal waters rather than conservative constituents reflecting only the mixing of water masses.
\end{abstract}

\section{INTRODUCTION}

Studies of planktonic bacteria of whole estuaries are few, in spite of the recognized importance of estuaries and now apparent significance of bacterial activities in planktonic ecosystems. Among the published studies are several descriptions of seasonal and spatial variations employing epifluorescent direct counting. Only one of these studies (Palumbo and Ferguson, 1978) was done in a salt-marsh estuary, in this case the Newport River estuary in North Carolina, USA. These workers sampled a broad range of the estuary over a 6 mo period, from June to December 1974. They concluded that the upper reaches of the estuary were a source of bacteria which then mixed with coastal seawater as a conservatively distributed 'substance' in the lower reaches of the estuary. No clear seasonal pattern emerged from this study other than a lowering of numbers in November and December.

\footnotetext{
- Present address: College of Marine Studies, University of Delaware, Lewes, Delaware 19958, USA
}

Bent and Goulder (1981) studied numbers and activity of bacteria for $2 \mathrm{yr}$ in the Humber Estuary in northeast England. In this highly polluted estuary, the seasonal pattern indicated a low in summer and high numbers from autumn to spring. This pattern is a consequence of the fact that most of the bacteria were attached to suspended solids. The Fraser River estuary in British Columbia is also characterized by high turbidity and a large proportion of particulate bacteria (Bell and Albright, 1981). Total counts showed an inverse trend with salinity, although heterotrophic activity of the bacteria was generally highest in the plume water of intermediate salinity.

Numerous other studies have indicated that heterotrophic activity, on a per cell basis, is higher in estuarine waters than in the connecting fresh or marine waters (Stevenson and Erkenbrecher, 1976; Wright, 1978; Goulder et al., 1980). In summary, from the published studies on estuarine bacteria, it is safe to conclude that few clear patterns have appeared. Certainly much of the reason for this can be traced to the differences between the estuaries studied. Some, how- 
ever, is due to the limited frequency of sampling, both spatial and temporal.

This paper represents the first of a series based on several years of work with the planktonic bacteria in several small salt-marsh estuaries and the connecting coastal waters in northern Massachusetts. The goal of this present paper is to establish some basic information on patterns of spatial and temporal variations in bacteria numbers and activity in the estuaries.

\section{STUDY AREA}

The work reported here is the result of a year-long study of bacteria numbers and activity in 1 estuary (Essex), and a number of comparative investigations of

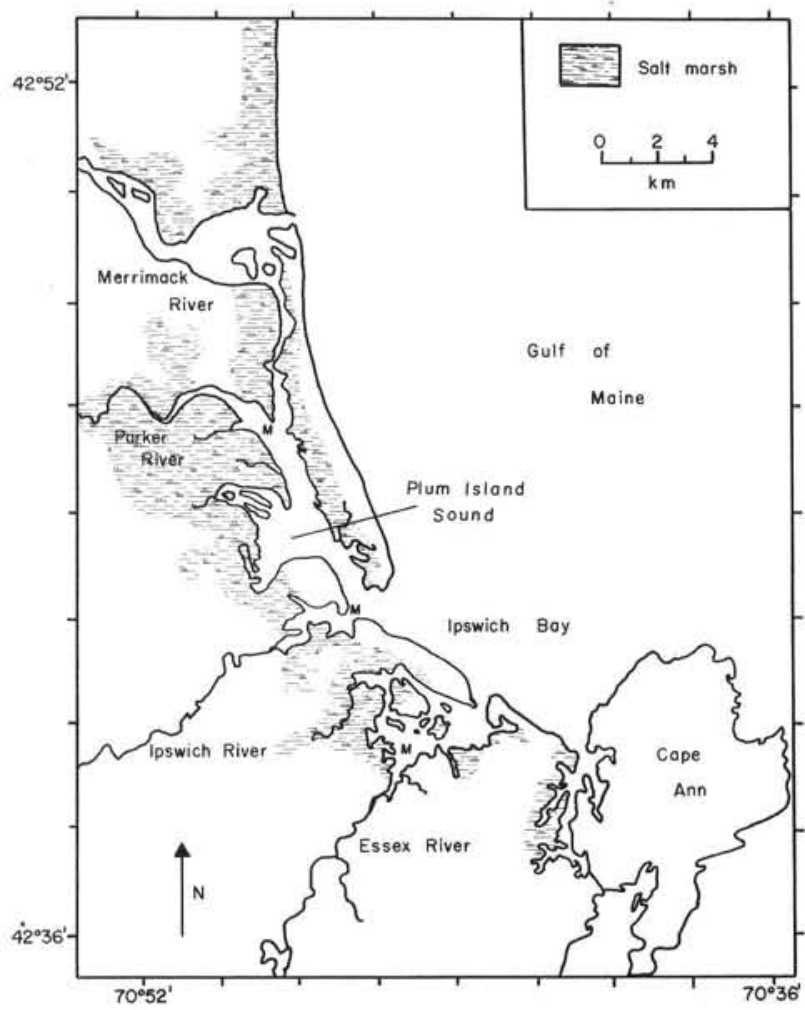

Fig. 1. Location of Essex, Ipswich and Parker River estuaries in northern Massachusetts, USA. ' $\mathrm{M}$ ' beginning of river sections of Parker, Ipswich and Essex estuaries, respectively the spatial distribution in 3 estuaries (Essex, Ipswich, Parker). These estuaries are located in the North Shore region of the Massachusetts coast between Cape Ann and the New Hampshire border (Fig. 1). The 3 are similar in that they are relatively unpolluted, small and are extensively bordered by Spartina salt marshes before they empty into Ipswich Bay, a coastal region of

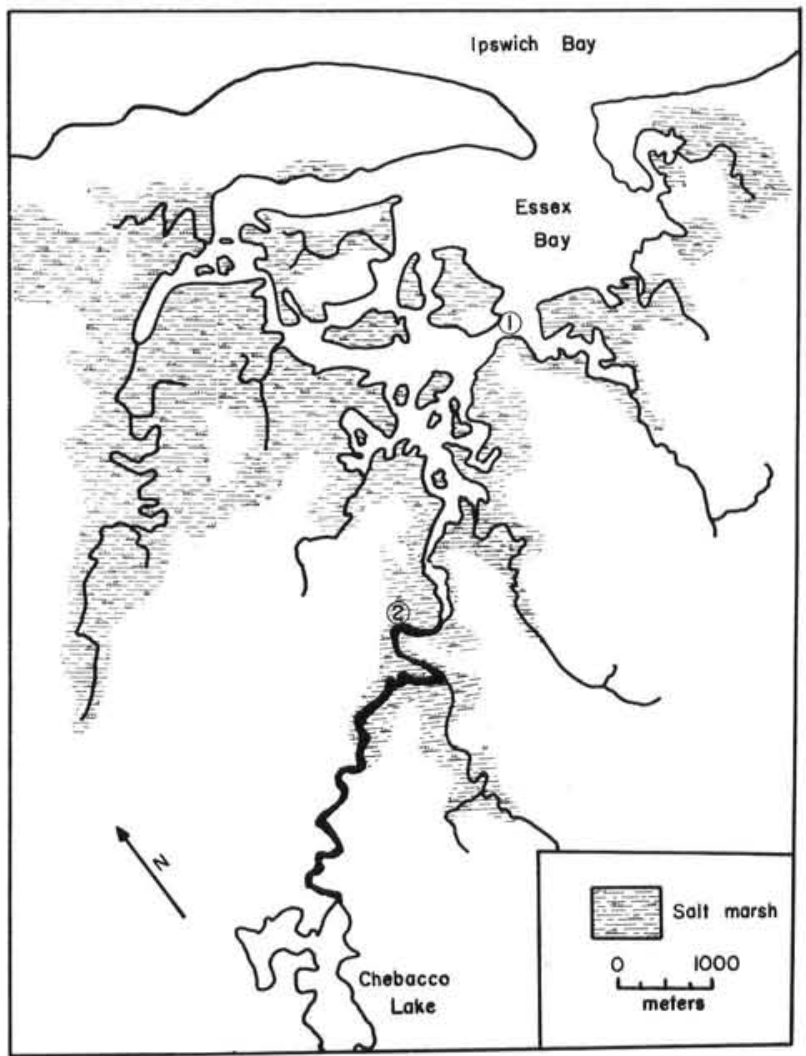

Fig. 2. Essex River estuary. 1: seaward fixed sampling station (E10), $2.6 \mathrm{~km}$ in from Ipswich Bay; 2: upper estuary fixed sampling station (E5), $7.1 \mathrm{~km}$ upriver from Ipswich Bay, used in year's cycle sampling

the Gulf of Maine. Differences between the systems are found primarily in their physical structures: length, freshwater flow, area of salt marsh, and area of high tide and low tide waters (summarized in Table 1). The Ipswich system has the highest freshwater flow but is

Table 1. Physical parameters of the Parker, Essex and Ipswich River estuaries. Area and length measurements are from US Geological Survey and nautical charts. Area measurements were obtained with a planimeter

\begin{tabular}{|lcccrc|}
\hline \multicolumn{1}{|c}{ Site } & $\begin{array}{c}\text { Length } \\
(\mathrm{km})\end{array}$ & $\begin{array}{c}\text { Low water } \\
\text { (area in ha) }\end{array}$ & $\begin{array}{c}\text { High water } \\
\text { marsh }\end{array}$ & $\begin{array}{c}\text { Mean } \\
\text { freshwater input }\end{array}$ \\
\hline Parker River \& Plum Is. Sound & 24.2 & 691 & 1425 & 2481 & $0.92 \mathrm{~m}^{3} \mathrm{~s}^{-1}$ \\
Essex River \& Essex Bay & 10.7 & 379 & 1128 & 1115 & $0.42 \mathrm{~m}^{3} \mathrm{~s}^{-1}$ \\
Ipswich River & 5.5 & 30 & 158 & 485 & $5.5 \mathrm{~m}^{3} \mathrm{~s}^{-1}$ \\
\hline
\end{tabular}


also the shortest estuary. It connects directly with Ipswich Bay. The Parker is the longest estuary, has the most extensive salt marsh border and connects with Plum Island Sound, a larger embayment. The Essex is intermediate in length and salt marsh development and has the lowest freshwater flow. The Essex also connects with an embayment, Essex Bay, before joining coastal Ipswich Bay. It is safe to say that during most of the year, tidal exchange (mean range of $2.6 \mathrm{~m}$ ) rather than freshwater flushing dominates the hydrological and biological characteristics of these estuaries. Fig. 2 shows the Essex estuary system. Locations of the fixed sampling stations used in the yearlong study are indicated by circled numbers.

\section{METHODS}

\section{Sampling}

Sampling for the year's cycle study of the Essex river from the 2 fixed sites (Fig. 2) consisted of taking surface water every $45 \mathrm{~min}$ from just before low slack to just after high slack tide on a monthly basis. This usually resulted in 9 samples from each site. One $100 \mathrm{ml}$ aliquot from each sample was preserved with $5 \mathrm{ml}$ buffered, filtered formalin for later counting of total bacteria numbers. To measure heterotrophic activity, a second $100 \mathrm{ml}$ aliquot was added to a stoppered serum bottle and amended with $50 \mu \mathrm{l}$ of a ${ }^{14} \mathrm{C}$ glutamate solution containing $0.47 \mu \mathrm{Ci}$, giving a concentration of $1.2 \mu \mathrm{g} 1^{-1}$ glutamate in the sample. A third $100 \mathrm{ml}$ aliquot was taken for alternate samples fixed with formalin $(5 \mathrm{ml}$ to $100 \mathrm{ml})$ and treated indentically as the live sample with the ${ }^{14} \mathrm{C}$-glutamate. This served as the blank. Water temperature and stage of tide were recorded for each sample. Blanks and live samples were incubated in the field from $3 / 4$ to $3 \mathrm{~h}$ (depending on temperature) in a covered cooler held at natural temperature with fresh sample water. Incubation was terminated in the laboratory by filtration. Each heterotrophic uptake sample was subdivided into four $25 \mathrm{ml}$ aliquots, and the 4 aliquots were filtered through $0.2,0.4,0.6$ and $1.0 \mu \mathrm{M}$ pore size Nuclepore filters, respectively. The filters were placed in Nalgene sleeves (Nalge Company, Rochester, NY) and dried in a $50{ }^{\circ} \mathrm{C}$ oven overnight. Following this, $3 \mathrm{ml}$ of a scintillation cocktail was added, the sleeves were heatsealed, and the samples were counted in a Searle Delta 300 Liquid Scintillation Counter. Quenching was corrected with the channels ratio method. Uptake data were blank-corrected and assimilation turnover rate calculated (Wright, 1978) and expressed as the actual rate times $10^{3} \mathrm{~h}^{-1}$ (note that this is the inverse of turnover time, and is fundamentally a tracer approach to kinetics; see Wright and Burnison, 1979). Bacteria in formalin-preserved samples were counted with the acridine orange direct count method of Hobbie et al. (1977). Counts were made in a semi-darkened enclosure with a Zeiss Standard microscope equipped for epifluorescence with acridine orange. As with the heterotrophic activity measurements, the counts were fractionated by dividing a sample into 4 aliquots and filtering through $0.2,0.4,0.6$ and $1.0 \mu \mathrm{M}$ Nuclepore filters, respectively. Bacteria on a given filter were counted until the accumulated number reached at least 200 cells. Subsequent data treatment for counts and activity involved separating out fractions by subtraction of the $0.4,0.6$ and $1.0 \mu \mathrm{M}$ results from the next smaller filter's value, yielding 4 fractions and a total value $(0.2-0.4 \mu \mathrm{m}, 0.4-0.6 \mu \mathrm{m}, 0.6-1.0 \mu \mathrm{m},>1.0 \mu \mathrm{m}$ and total).

Salinity was determined by conductivity for values below $5 \mathrm{ppt}$, and by density hydrometers or refractometer for higher salinity samples.

Sampling of the distribution of bacteria and other parameters for comparison purposes in the 3 estuaries was accomplished by either sampling all 3 in $1 \mathrm{~d}$, or over a 2 or $3 \mathrm{~d}$ period. Sampling runs were timed so as to sample each estuary at or close to a high-tide condition. Five samplings for comparative purposes were accomplished, spread out over a 4-yr period and involving sampling from spring, early and mid-summer, and fall. Unless otherwise stated, samples were taken with a scrubbed Van Dorn type sampler from $1 \mathrm{~m}$ depth.

\section{Data analysis}

Data analysis was facilitated with the use of a statistics software package and a PDP 11/70 Digital Computer. To aid in differentiation of water masses sampled, 4 subsample sets were isolated from the data collected on each date, and entered into 4 data files. The subsample sets (E5L0, E5HI, E10L0, E10HI) are described in detail in the 'Results' section. The approximate locations of these water masses at low tide and high tide in a profile of the estuary are shown in Fig. 3.

Correlation matrices were calculated for each data file, for variables assumed to be normally distributed (e.g. counts and activity and the size fractions thereof). For relations between dependent and independent variables (e.g. counts vs. temperature), linear regression analysis was used. Because sample sizes are large, many of the correlations and regressions were found to be significant but not strong, and therefore not very meaningful. Only the most obvious relations in the data will be discussed. 


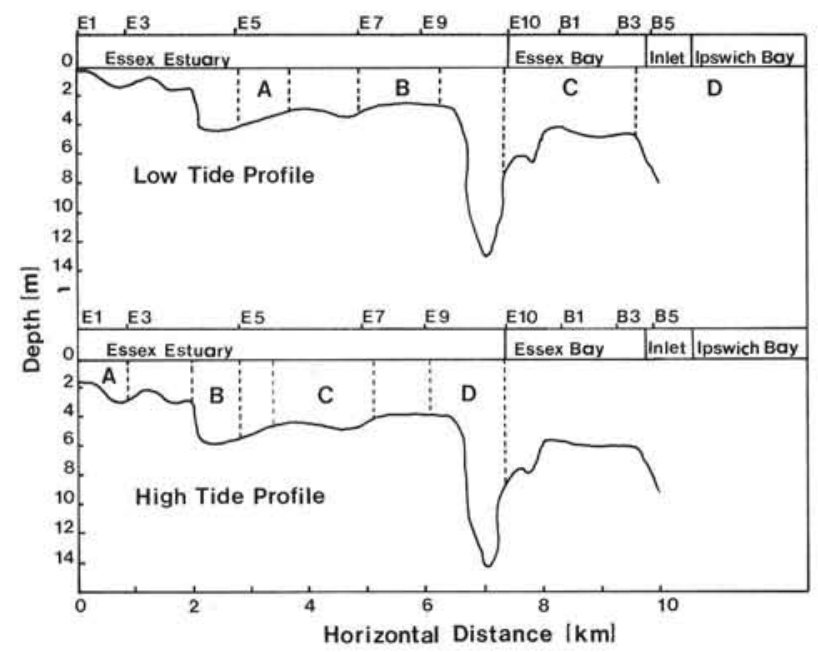

Fig. 3. Diagrammatic display of low and high tide vertical and longitudinal profiles of the Essex estuary system, showing the approximate location of 4 water masses used in year's cycle data analysis. $\mathrm{A}=\mathrm{E} 5 \mathrm{L0}, \mathrm{B}=\mathrm{E} 5 \mathrm{HI}, \mathrm{C}=\mathrm{E} 10 \mathrm{L0}, \mathrm{D}=\mathrm{E} 10 \mathrm{HI}$

\section{RESULTS}

\section{Year's cycle in the Essex estuary}

Sampling for this study was begun in October 1977 and terminated the following October. Distance between the 2 fixed sampling stations was $4.5 \mathrm{~km}$, resulting in a small sampling gap between high-tide water at upriver station (E-5) and the low-tide water at the downriver station $(\mathrm{E}-10)$. Otherwise, the sampling regime proved adequate for the broad range of water within the estuary. A total of 239 samples was collected and analysed in the course of the study.

Figs. 4 and 5 show the total bacteria count data (AODC) from 12 mo displayed horizontally according to the stage of the flooding tide corresponding to when they were sampled. These data display several important facts. Clearly, the horizontal distribution of bacteria in the estuary is uniform at some times of the year, and is quite otherwise at other times. During winter, numbers show little variation up and down the estuary, between ca. 0.5 and $1.0 \times 10^{6} \mathrm{ml}^{-1}$. However, during spring a peak of bacteria gradually develops in midestuarine waters, and the high numbers there are sustained through summer and then subside during fall. The total seasonal range of numbers in mid-estuarine waters is 10 -fold, and much less (4-fold) in the predominantly coastal water which occurs toward the end of the flood tide at the seaward station. Fig. 6 represents this difference between mid-estuarine and coastal waters by showing typical levels reached by the bacteria during the course of a year in the two types of water.

\section{Statistical relations}

\section{Characteristics of subsample sets}

The sampling regime employed made possible the differentiation of 4 water masses according to stage of tide (Fig. 3). The set referred to as E5L0 represents all samples collected at the upriver station between low slack tide and 0.3 into the flood tide. This is upper estuary water, and is usually quite brackish. Set E5HI

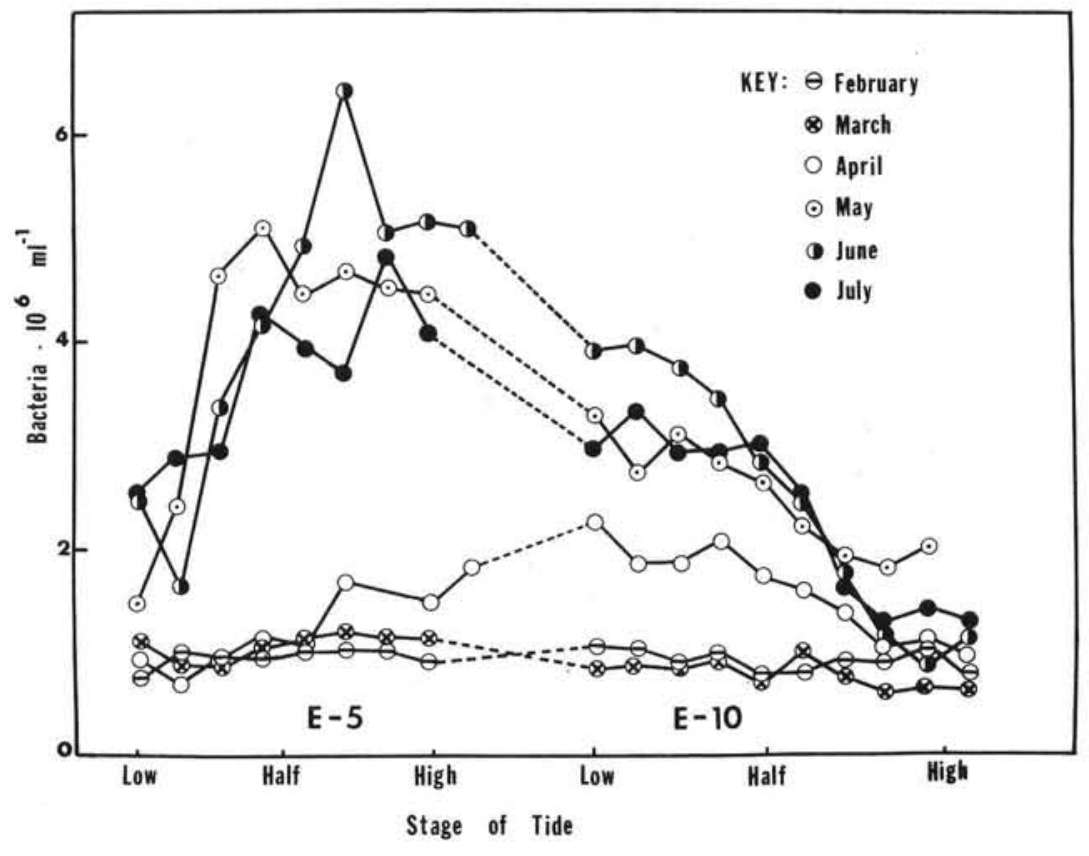

Fig. 4. Direct counts of bacteria, February through July, 1978, in the Essex estuary, as a function of stage of tide when samples were taken 
Fig. 5. Direct counts of bacteria, August through January, 1977 and 1978, in the Essex estuary, as a function of stage of tide when samples were taken

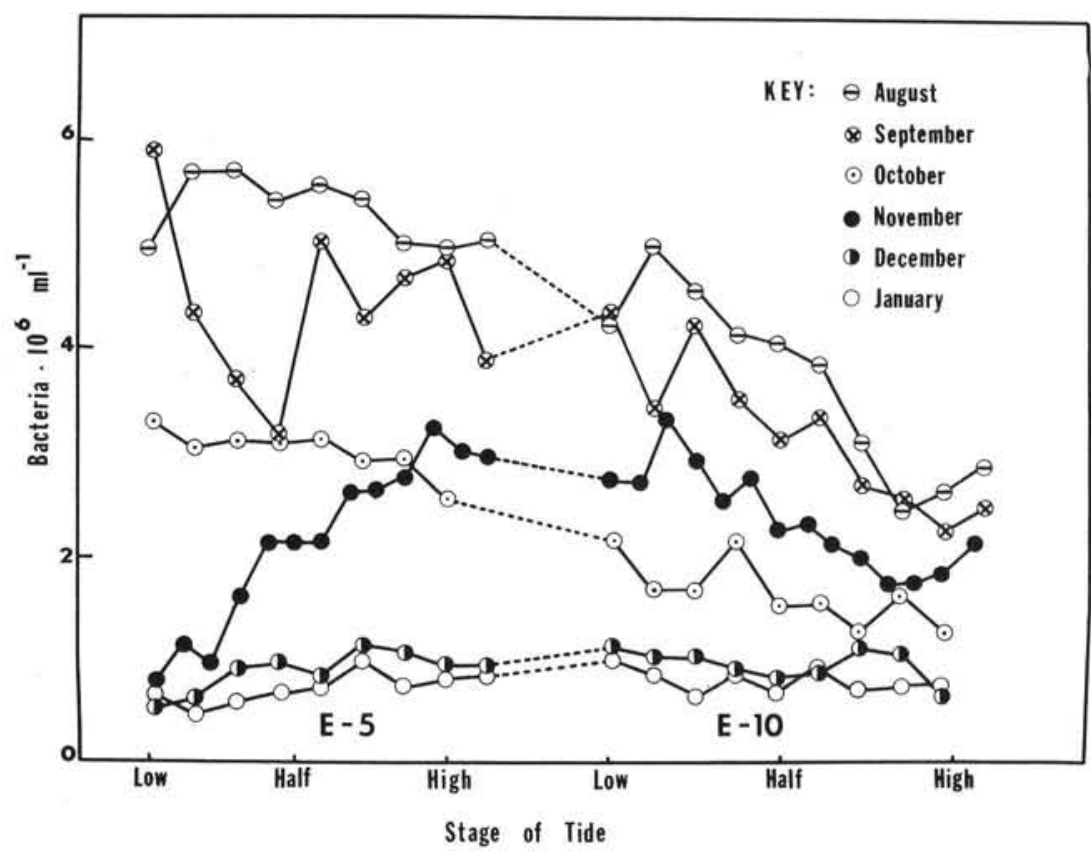

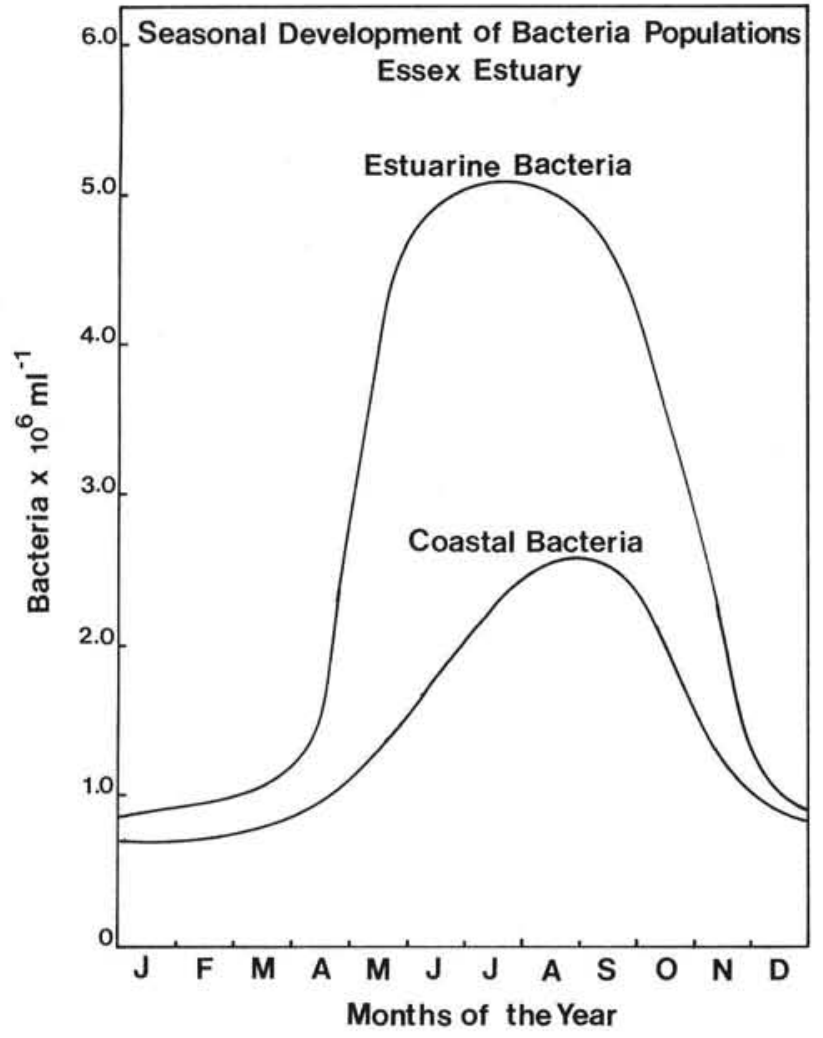

Fig. 6. Seasonal development pattern of estuarine and coastal water bacterial flora (total counts) in the Essex River - Ipswich Bay system

comprises all samples collected from the upriver station from 0.7 of the flood-tide duration to high slack tide. This is mid-estuary water which on a single tidal cycle (neglecting net discharge or exchange) remains in the estuary proper. Set E10L0 comprises all those samples from the seaward sampling station collected between low slack tide and 0.5 into the flood-tide cycle. This water is in Essex Bay at low tide and in the salt-marsh area of the estuary at high tide. Set E10HI represents samples taken from 0.75 of the flood tide to high slack, and refers to water that is in Ipswich Bay at low tide (coastal water, therefore) and in the lower estuary at high tide. Mean data for salinity, heterotrophic activity and bacteria counts are given in Table 2 . These data show in a very broad way the

Table 2. Salinity, heterotrophic activity and direct counts of bacteria for 4 water masses used in year's cycle data analysis, Essex estuary. Means, with standard deviations in parentheses

\begin{tabular}{|lccc|}
\hline Water mass & $\begin{array}{c}\text { Salinity } \\
\text { (ppt.) }\end{array}$ & $\begin{array}{c}\text { Total activity } \\
\left(\times 10^{-3} \mathrm{~h}^{-1}\right)\end{array}$ & $\begin{array}{c}\text { Total counts } \\
\left(\times 10^{6} \mathrm{ml}^{-1}\right)\end{array}$ \\
\hline $\begin{array}{l}\text { E5LO } \\
\text { (upper estuary) }\end{array}$ & $10.0(10.2)$ & $46.0(50.3)$ & $2.19(1.50)$ \\
$\begin{array}{l}\text { E5HI } \\
\text { (mid estuary) }\end{array}$ & $24.6(6.7)$ & $70.5(67.6)$ & $3.12(1.67)$ \\
$\begin{array}{l}\text { E10LO } \\
\text { lower estuary) } \\
\begin{array}{l}\text { E10HI } \\
\text { (coastal) }\end{array}\end{array}$ & $29.1(2.4)$ & $40.9(36.9)$ & $2.47(1.19)$ \\
\hline
\end{tabular}

trends of heterotrophic activity and counts in the estuarine-coastal water system. Activity and counts appear to be related and follow the same pattern of highest values in mid-estuary, somewhat lower upriver and considerably lower in coastal water. 
Table 3. Correlation coefficients for total counts and heterotrophic activity with size fractions. Values in parentheses are mean percentages each fraction represents of total value for each sample

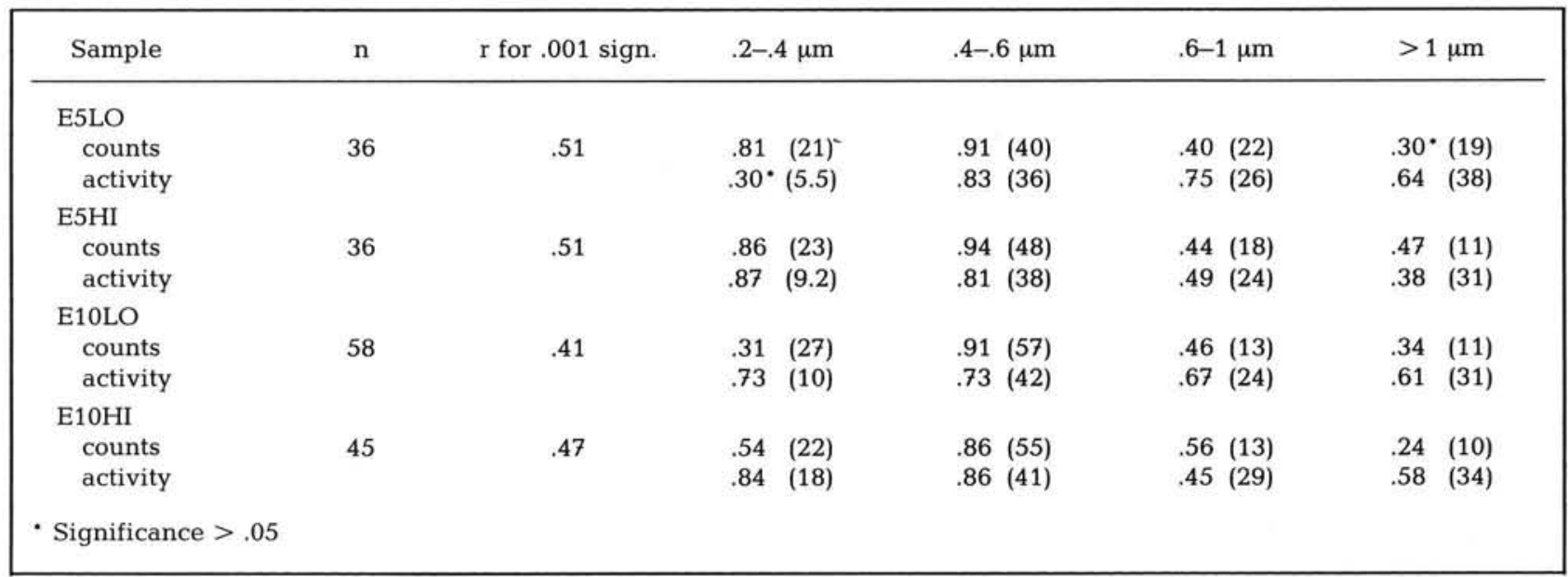

Contribution of fractions to total numbers and activity

In the sampling procedure different pore size filters were used to determine the relative contribution of different size fractions to counts and activity. Total counts and heterotrophic activity represent the results from all organisms retained on the $0.2 \mu \mathrm{m}$ filters, and the 4 fractions were compared with these total values to evaluate possible relationships between a given fraction and the total. Table 3 lists coefficients of correlation between the fractions and the total counts or heterotrophic activity. The fraction showing the strongest correlations with both counts and activity is the 0.4 to $0.6 \mu \mathrm{m}$ fraction. As would be expected, this fraction also makes up the largest proportion of the total cell count for all areas of the estuary. There are some interesting progressions shown in Table 3 for data from the different water masses of the estuary. The size pattern, as revealed by percentage means, demonstrates a shift from larger to smaller cells in going from upper estuary water (E5L0) to coastal water $(\mathrm{E} 10 \mathrm{HI})$. Mean percentages for activity demonstrate increasingly greater activity in the smaller size fractions following the same gradient. The smallest 2 size fractions show the strongest correlations with the total heterotrophic activity measurements, for all but the upper estuary smallest activity fraction ( 0.2 to $0.4 \mu \mathrm{m})$.

\section{Relationships between counts and activity}

Table 4 gives correlations between counts and activity, broken down for the 4 fractions and also for total values from the 4 water masses. Not suprisingly, the 0.4 to $0.6 \mu \mathrm{m}$ fraction consistently gave the highest correlation; other fractions showed lower or non-existent correlation between counts and activity. One reason for this lack of correlation relates to the fact that the counts were based on fractionation of formalinfixed bacteria, while heterotrophic activity fractionation was performed on live samples. We have found that formalin fixation affects fractionation by shifting apparent sizes into larger categories. The correlation between total counts and total activity was very strong. In 2 of the 4 water masses, transformation of the activity data to natural logs improved the strength of the correlation substantially. These 2 water masses represent the water that circulates entirely within the estu-

Table 4. Correlation coefficients between counts and heterotrophic activity for fractions and totals, year's cycle data in Essex estuary

\begin{tabular}{|lcccccccc|}
\hline Sample & $\mathrm{n}$ & $\begin{array}{c}\mathrm{r} \text { for } \\
.001 \text { sign. }\end{array}$ & $.2-.4 \mu \mathrm{m}$ & $.4-.6 \mu \mathrm{m}$ & $.6-1 \mu \mathrm{m}$ & $>1 \mu \mathrm{m}$ & Totals & $\begin{array}{c}\text { Total cts. \& } \\
\text { ln activity }\end{array}$ \\
\hline E5LO & 36 & .51 & $-.13 \cdot$ & .72 & $-.03 \cdot$ & .35 & .75 & .76 \\
E5HI & 36 & .51 & .52 & .60 & $-.01 \cdot$ & .47 & .73 & .84 \\
E10LO & 58 & .41 & .12. & .52 & $-.02 \cdot$ & .31 & .54 & .63 \\
E10HI & 45 & .47 & $.15 \cdot$ & .87 & .49 & .42 & .74 & .73 \\
Significance $>.05$ & & & & & & & & \\
\hline
\end{tabular}


ary but is not strongly influenced by daily freshwater inflow (Fig. 3).

\section{Regression analysis of total counts and activity data}

The total counts and activity data were subjected to regression analysis using a stepwise multiple regression procedure. Independent variables employed were: salinity, temperature, stage of tide, and, for activity data, counts. The procedure invariably selected temperature as that variable accounting for the greatest reduction of variance in counts, ranging from $58 \%$ to $88 \%$ as shown by the coefficient of determination values (Table 5). Only in 1 case (E5L0) did the stepwise procedure indicate a significant additional reduction in variance due to a 2 nd variable. Here, salinity accounted for an additional $9.8 \%$ reduction in variance. Individual regression of total counts on salinity for this sample revealed a positive regression coefficient (.116), an intercept of $1.034 \times 10^{6} \mathrm{ml}^{-1}$, and a coefficient of determination $\left(\mathrm{r}^{2}\right)$ of .62 . The individual regression coefficients and intercepts shown in Table 5 demonstrate a much stronger dependence of counts on temperature for mid-estuarine water than for coastal water.

Stepwise regression applied to heterotrophic activity data selected temperature as the first variable in all but the E10HI water. In the latter case, bacteria counts accounted for a $53 \%$ reduction in variance, with temperature contributing an additional $2.7 \%$ reduction. The regression of activity on temperature showed greater variability than the bacteria count data on temperature, as indicated by the coefficients of determination $\left(\mathrm{r}^{2}\right)$. However, when activity data were transformed to ln activity, there was a substantial improvement in the regression fit to temperature for all 4 water masses (Table 5). To summarize, bacteria counts are strongly related to temperature throughout the estuary; quantitatively, the dependence is greatest in upper and mid-estuarine waters. Where freshwater contribution is greatest (E5L0), bacteria counts increase significantly with increasing salinity. Strong temperature dependence is also indicated by heterotrophic activity, the relationship being best expressed as a semi-log dependence of activity on temperature. Again, the greatest dependence is seen in upper and midestuarine waters as opposed to coastal water.

\section{BACTERIA DISTRIBUTION IN OTHER ESTUARIES}

The sampling for the year's cycle study in the Essex system showed a maximum in bacteria numbers in mid-estuarine waters (Figs. 4 and 5). The maximum developed during spring persisted throughout summer and subsided during fall. Although there is greater sample-to-sample variability, the data on heterotrophic activity show the same pattern, as reflected by the strong correlations between counts and activity (Table 4) and the direct relation between activity and temperature (Table 5). In order to determine whether the patterns seen in the Essex occurred in other estuaries, the Parker, Ipswich and Essex estuaries were sampled at similar times and tides. Fig. 7 shows data from 2 sampling dates for the 3 estuaries, taken in midsummer when the estuarine population in the Essex was well-developed. It is evident from these data that in spite of the different salinity regimes and different physical parameters, the Parker and Ipswich estuaries also show an enriched bacteria population in the upper estuarine waters. As these were high-tide samples, they do not show the bacteria concentrations in the headwaters of the estuaries, which in the Essex and Ipswich estuaries would be lower and give the appearance to the data of the peak in numbers seen in the Parker River, and in much of the year's cycle data from the Essex.

To facilitate a better comparison of these estuaries, sampling stations were represented by their linear distance from the beginning of the 'river' section of each estuary (marked $\mathrm{M}$ on Fig. 1), and bacteria count data from each of the 5 comparison samplings were plotted versus these measured distances. Fig. 8 shows the data for the 3 estuaries from the July 6, 1981

Table 5. Regression of heterotrophic activity and total counts on temperature, year's cycle data in Essex estuary. $\mathrm{r}^{2}=$ coefficient of determination

\begin{tabular}{|c|c|c|c|c|c|c|c|c|c|}
\hline \multirow[t]{2}{*}{ Sample } & \multicolumn{3}{|c|}{ Activity $\left(\times 10^{-3} \mathrm{~h}^{-1}\right)$} & \multicolumn{3}{|c|}{ Nat. log activity } & \multicolumn{3}{|c|}{ Total counts $\left(\times 10^{6} \mathrm{~m}^{-1}\right)$} \\
\hline & $\begin{array}{l}\text { regr. } \\
\text { coeff. }\end{array}$ & interc. & $r^{2}$ & $\begin{array}{l}\text { regr. } \\
\text { coeff. }\end{array}$ & interc. & $r^{2}$ & $\begin{array}{l}\text { regr. } \\
\text { coeff. }\end{array}$ & interc. & $\mathrm{r}^{2}$ \\
\hline E5LO & 5.44 & -1.80 & .71 & .163 & 1.55 & .83 & .169 & 0.54 & .76 \\
\hline E5HI & 6.13 & 1.51 & .66 & .115 & 2.42 & .82 & .177 & 1.11 & .88 \\
\hline E10LO & 3.33 & 13.3 & .46 & .097 & 2.48 & .60 & .141 & 1.17 & .79 \\
\hline $\mathrm{E} 10 \mathrm{HI}$ & 3.54 & -3.35 & .46 & .124 & 1.58 & .57 & .074 & 0.80 & .58 \\
\hline
\end{tabular}



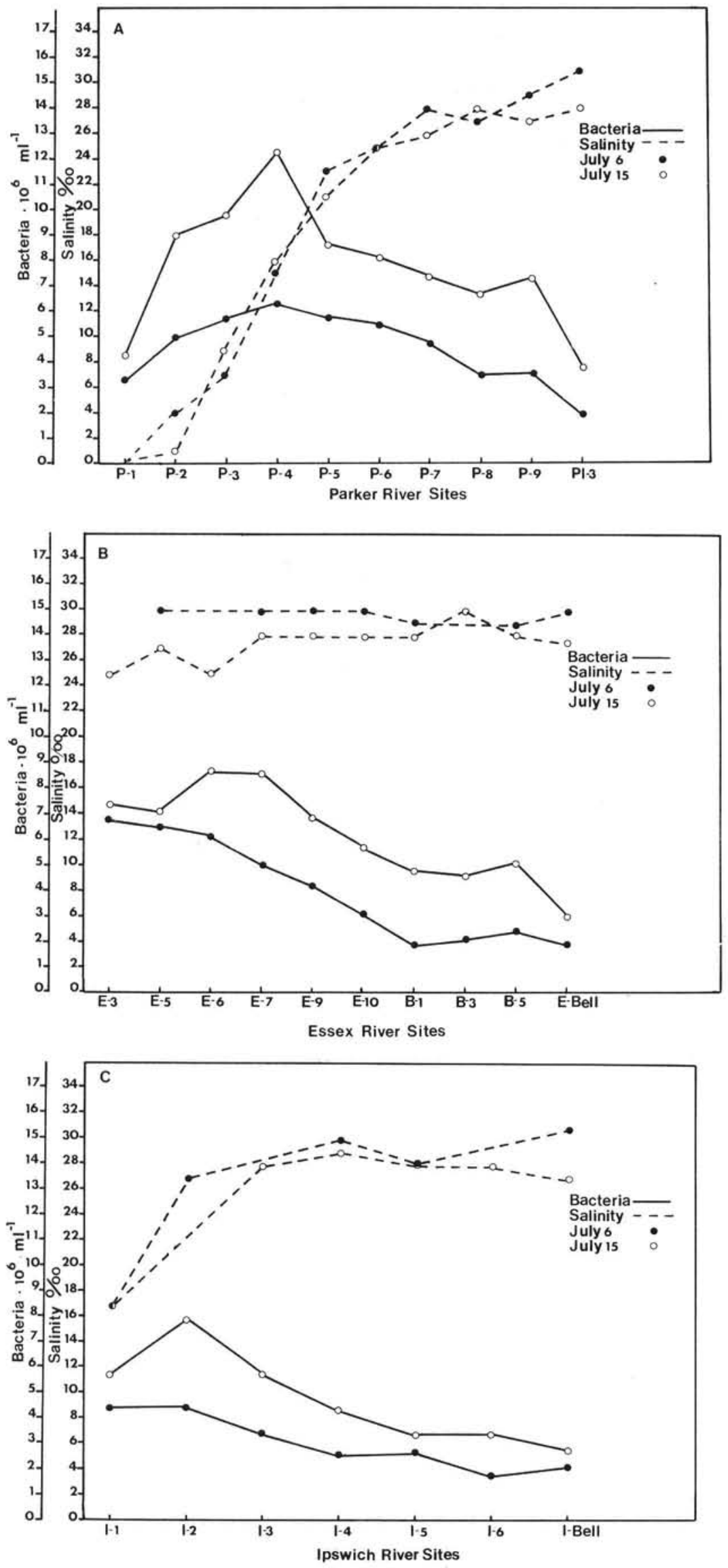

Fig. 7. High-tide distribution of bacteria (AODC) and salinity in the Parker, Essex and Ipswich estuary systems on July 6 and July 15, 1981 (upriver to left, ocean to right) 


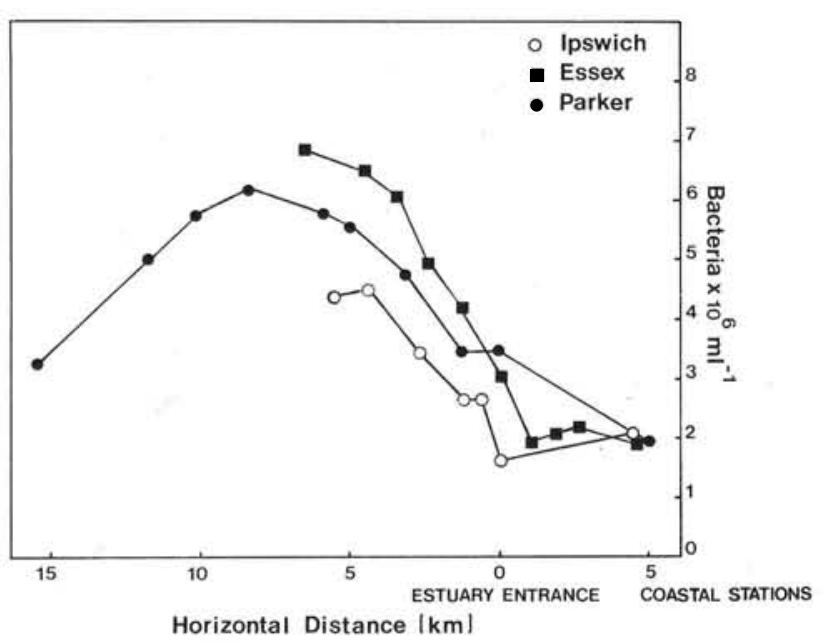

Fig. 8. High-tide distribution of bacteria (AODC) in the Parker, Essex and Ipswich estuary systems on July 6, 1981, plotted according to distance from mouth of river region of estuary

Table 6. Regression of bacteria counts on length of estuary from mouth of estuary upriver to maximum population. Significance tested with Student's $\mathrm{t}$, critical $\mathrm{t}$ set at $\mathrm{P}=.05$. Units: regr. coeff., $10^{6}$ bacteria $\mathrm{ml}^{-1} \mathrm{~km}^{-1}$; intercept, $10^{6}$ bacteria $\mathrm{ml}^{-1}$

\begin{tabular}{|c|c|c|c|c|c|}
\hline \multicolumn{2}{|l|}{ Dates } & $\begin{array}{l}\text { Es- } \\
\text { sex }\end{array}$ & $\begin{array}{c}\text { Par- } \\
\text { ker }\end{array}$ & \multirow{2}{*}{$\begin{array}{c}\text { Ips- } \\
\text { wich }\end{array}$} & $\begin{array}{c}\begin{array}{c}\text { All } \\
\text { three }\end{array} \\
.192\end{array}$ \\
\hline $\begin{array}{l}\text { 10/31/77 } \\
11 / 1 / 77\end{array}$ & $\begin{array}{l}\text { Regr. coeff. } \\
\text { st. error } \\
\text { interc. } \\
\quad n \\
\text { None of regr }\end{array}$ & $\begin{array}{c}.456 \\
.189 \\
3.04 \\
5 \\
\text { coeff. }\end{array}$ & $\begin{array}{c}.153 \\
.042 \\
3.23 \\
8 \\
\text { gnific }\end{array}$ & & .192 \\
\hline $\begin{array}{l}6 / 26 / 79 \\
6 / 28 / 79\end{array}$ & $\begin{array}{l}\text { Regr. coeff. } \\
\text { st. error } \\
\text { interc. } \\
\quad n \\
\text { None of regr }\end{array}$ & $\begin{array}{c}.345 \\
.107 \\
4.05 \\
6 \\
\text { coeff. }\end{array}$ & $\begin{array}{c}.393 \\
.074 \\
3.60 \\
6 \\
\text { gnific }\end{array}$ & $\begin{array}{c}.449 \\
.098 \\
2.94 \\
4 \\
\text { ly diff }\end{array}$ & .383 \\
\hline $5 / 29 / 81$ & $\begin{array}{l}\text { Regr. coeff. } \\
\text { st. error } \\
\text { interc. } \\
\quad \mathrm{n}\end{array}$ & $\begin{array}{c}1.04^{\circ} \\
.112 \\
3.24 \\
6\end{array}$ & $\begin{array}{c}.229 \\
.039 \\
4.05 \\
5\end{array}$ & $\begin{array}{c}.118 \\
.086 \\
1.89 \\
5\end{array}$ & $.191^{\cdots}$ \\
\hline $7 / 6 / 81$ & $\begin{array}{l}\text { Regr. coeff. } \\
\text { st. error } \\
\text { interc. } \\
\quad n \\
\text { None of regr }\end{array}$ & $\begin{array}{c}.604 \\
.098 \\
3.48 \\
6 \\
\text { coeff. }\end{array}$ & $\begin{array}{c}.376 \\
.045 \\
3.39 \\
6 \\
\text { gnific }\end{array}$ & $\begin{array}{c}.564 \\
.077 \\
2.00 \\
5 \\
1 y \text { dif }\end{array}$ & .468 \\
\hline $7 / 15 / 81$ & $\begin{array}{l}\text { Regr. coeff. } \\
\text { st. error } \\
\text { interc. } \\
\quad \mathrm{n}\end{array}$ & $\begin{array}{c}.995 \\
.117 \\
5.77 \\
5\end{array}$ & $\begin{array}{l}.751 \\
.166 \\
5.07 \\
5\end{array}$ & $\begin{array}{c}1.08 \\
.081 \\
3.06 \\
5\end{array}$ & .884 \\
\hline $\begin{aligned} \text { - Signifi } & \text { Somm } \\
& \begin{array}{l}\text { Conly } \\
\text { onl }\end{array}\end{aligned}$ & $\begin{array}{l}\text { cantly differer } \\
\text { on regression }\end{array}$ & $\begin{array}{l}\text { from } \\
\text { eeffici }\end{array}$ & $\begin{array}{l}\text { e oth } \\
\text { it for }\end{array}$ & $\begin{array}{l}\text { stuar } \\
\text { ker an }\end{array}$ & Ipswich \\
\hline
\end{tabular}

sampling (also seen in Fig. 7). This figure indicates that the increment of bacteria with linear distance up each estuary appears to be very similar (although starting populations differ), suggesting that similar processes may be operating to allow the development of a typical estuarine bacteria population in these 3 estuaries. To analyse this relationship further, bacteria counts and linear distance for each estuary were subjected to linear regression analysis. The analysis was applied to counts from the lowest seaward concentration, upriver to the peak population for a given estuary. Table 6 lists the results of the analysis for all 5 comparative samplings of the 3 estuaries. Individual regression coefficients are essentially an expression of the increment of bacteria, in millions of cells per $\mathrm{ml}$, with each $\mathrm{km}$ of linear distance upriver in an estuary. The intercept gives an expression of the seaward endmember bacteria populations with which the estuary is mixing. In only one case (Essex river, 5/29/81) are the estuaries sigificantly different from each other for the development of bacteria with upriver linear distance. However, the regression coefficients reflect some very large differences between sampling dates, as would be expected given the seasonal development of the estuarine population presented earlier. Also, the Ipswich estuary consistently shows the lowest seaward end-member bacteria population, a consequence of the fact that this system connects directly with coastal water and not via an embayment.

We have collected data on bacterial activity and productivity from these 3 estuaries, to be reported in subsequent papers in this series. The differences in these data between the 3 estuaries are well within the magnitude of differences found within a given estuary, and are directly related to the magnitude of the bacteria population, given equal temperatures. The fundamental problem, then, is to explain why a given bacteria concentration is found in a given water mass.

\section{DISCUSSION}

The data presented in this paper indicate clearly that, except for the winter months, the estuaries studied develop a bacterial flora several-fold higher in concentration than the freshwater or coastal seawater at either end of the estuary. The seasonal development of this estuarine flora is strongly linked to temperature, which in this geographical area ranges from -1 to $25^{\circ} \mathrm{C}$ yearly. Wilson and Stevenson (1980) also reported a strong relation between temperature and the bacterioplankton of a salt-marsh coastal system in South Carolina (USA), although no statistical evaluation was given. In a 2-yr study of bacteria in the brackish waters of the coastal Baltic Sea off Finland, Väätänen (1980) 
found temperature to be the most significant variable in a step-wise multiple regression for total bacteria counts.

Although in the present paper the relation between temperature and bacterioplankton is highly significant, it is not necessarily direct. Studies of short-term variations in the bacterioplankton have clearly indicated that short-term factors control fluctuations in the numbers of bacteria (Meyer-Reil et al., 1979; Fuhrman et al., 1980), a conclusion that is in keeping with the capabilities of bacteria for rapid growth. Among these factors, the availability of dissolved organic substrate is certain to be of primary importance. Estuarine bacteria are capable of responding rapidly to artificially added substrate, often increasing several-fold within a 24-h period (Wright, 1978; Wright, in press). Further, rapid growth of estuarine bacteria on natural substrate is readily measured by filtering a natural sample through a $3 \mu \mathrm{m}$ Nuclepore filter to remove algae and microzooplankton and then following net growth of the bacteria by periodic sampling (Wright, unpubl.). In salt marsh estuaries, the 2 major autochthonous substrate sources for heterotrophic bacteria are phytoplankton and salt-marsh grasses (Turner, 1978). Turner's work has indicated that in estuaries with a high ratio of marsh-to-water area, heterotrophic activity is most strongly linked to leachate derived from Spartina photosynthesis, which in turn is seasonally controlled by temperature. It is possible that the development of the mid-estuarine peak of bacteria observed in the 3 salt marsh estuaries studied, and its strong temperature dependence, can be explained as a consequence of substrate supply from Spartina photosynthesis. This might also explain why the relation between temperature and bacteria numbers was fundamentally different in coastal water versus estuarine water (Table 5).

The total seasonal range of numbers in midestuarine waters was only 10 -fold, and the range in coastal waters even lower (4-fold). Indeed, where studies have included observations over the seasons, the range reported has always been within an order of magnitude (Palumbo and Ferguson, 1978; Hågström et al., 1979; Väätänen, 1980; Larsson and Hågström, 1982). This is considerably less than the seasonal variation typically found for the phytoplankton (e.g. Larsson and Hågström, 1982). At the same time, studies where sampling of bacterial populations was performed at closer time intervals have shown as much as a 2 or 3-fold range within the course of a day (MeyerReil et al., 1979; Burney et al., 1981; Burney et al., 1982). The evidence thus indicates that, especially in estuarine waters, a particular population density of bacteria must be viewed as a steady-state system, fluctuating within bounds set by factors that are contributing to bacterial production (e.g. substrate sup- ply), and other factors that are operating to reduce bacteria numbers. Among the latter, grazing by microzooplankton (Haas and Webb, 1979) and benthic fauna (Wright et al., 1982) is probably the most significant, although the impact of grazing on the bacteria is not yet understood. The best evidence for its importance comes from experiments which demonstrate rapid increases of bacteria following filtration through a 1 or $3 \mu \mathrm{m}$ filter, compared with very little change in control samples (Gak et al., 1972; Fuhrmann and Azam, 1980).

There is evidence that some bacterial populations of coastal and offshore waters are in a state of relative dormancy, growing only slowly if at all (e.g. Stevenson, 1978; Wright, 1978; Morita, 1980; Wright, in press). These populations are also lower in density than those of more eutrophic systems. Such populations would not likely sustain a grazing microzooplankton fauna, since a threshold concentration of bacteria for grazing appears to be required (Fenchel, 1980). One possible explanation, then, for the surprisingly limited range of bacteria concentrations both seasonally and spatially is that at the low end, dormancy preserves a non-growing (or slowly growing) population which is below the grazing threshold. The winter situation may be a special case where 'dormancy' is inflicted on the entire estuarine bacterial flora because of low temperatures (substrate is also certainly less available), and grazing, becomes ineffective both because of low temperatures and bacteria populations below the threshold. At the high end, sustained bacterial growth generates a grazing zooplankton population, which usually prevents the density of bacteria from increasing to limits otherwise set by substrate supply.

The data comparing the bacterial flora of the 3 estuaries studied suggest that the mixing of water masses may contribute significantly to the development and maintenance of the typical estuarine distribution of bacteria during the warmer months of the year. One aspect of mixing involves the freshwater input to the estuaries, as the upper end-member of the potential estuarine bacteria population. Even if the freshwater bacteria were capable of surviving and flourishing in the estuaries, which is doubtful (Valdés and Albright, 1981), the contribution of bacteria from freshwater input is quite small for the Parker and Essex Rivers, and is always lower in concentration than the mid-estuarine waters (Fig. 4). It has already been pointed out that for the upper estuarine water of the Essex, bacteria counts show a strong positive regression on salinity.

A second aspect of mixing concerns the seaward end-member bacteria concentrations, which are always much lower than the mid-estuarine concentra- 
tions except during the winter months. The intercepts for regression of bacteria counts on distance up the estuaries (Table 6) indicate differences in seaward end-member concentrations, and it has already been noted that the Ipswich estuary has the lowest endmember concentration owing to its direct connection with coastal water. The Essex and Parker estuaries connect with coastal water through Essex Bay and Plum Island Sound, respectively.

The most interesting aspect of mixing is revealed by the data showing very similar increments of bacteria concentration proceeding upriver from the mouth of each of the estuaries. At high tide, the peak population for the longer 2 estuaries is found beyond a distance of $5 \mathrm{~km}$ upriver (Fig. 8), and usually not as far as $10 \mathrm{~km}$ upriver. Direct measurements of flood-tide excursion for average tides in these estuaries have revealed them to range from $8 \mathrm{~km}$ at the seaward end to $4 \mathrm{~km}$ further upriver (Wright, unpubl.). As argued earlier, it seems likely that the upriver increment of bacteria in these estuaries is largely a function of substrate supply as it is influenced by tidal circulation within the estuary. Peak numbers in the estuary are found at some distance greater than one tidal excursion upriver from the estuary mouth at high tide. Water masses above this distance are restricted to the estuary during tidal circulation, and have opportunity for repeated contact with the salt marshes bordering the estuary as well as for sustained development of all members of the plankton community. In this regard it is important to note that the drainage areas occupied by salt marsh in each system vary in proportion to the relative lengths of the estuaries, about 100 hectares of marsh per $\mathrm{km}$ of length (Table 1). If substrate for bacteria originates mainly in the salt marshes (Turner, 1978), and the 3 estuaries are subject to the same tidal range and variations, then it should not be surprising that they usually show similar increments of bacteria with distance for a given date, proceeding upriver to the location of the mid-estuarine peak. Different end-member concentrations and effects of different freshwater-induced tidal flushing are probably responsible for creating the different ranges of bacteria numbers between the estuaries. The downward trend of bacteria concentrations from the mid-estuarine peak to the upper end of the estuary is probably a consequence of freshwater input and/or reduced substrate supply as salt marshes become more narrow and eventually give way to freshwater marsh plants. The Ipswich estuary is short, ca. $5 \mathrm{~km}$, and is subject to more extensive freshwater-induced tidal flushing, hence it does not always show the midestuarine maximum characteristic of the Essex and Parker estuaries. Peterson (Pers. comm.) measured bacteria in the North River estuary of southern Massachusetts in August, 1981, and found a pro- nounced mid-estuarine peak about $9 \mathrm{~km}$ upriver from the estuary mouth, with an increment of ca. $1 \times 10^{6}$ bacteria $\mathrm{ml}^{-1} \mathrm{~km}^{-1}$ in the upriver direction. This estuary is similar to the Parker River system, and it seems likely that the factors discussed above are also responsible for the distribution of bacteria found by Peterson. Other published works involving the distribution of bacteria in estuaries (Bell and Albright, 1981; Bent and Goulder, 1981) deal with such fundamentally different systems that a comparison of results is not possible.

Palumbo and Ferguson (1978) suggested that the bacteria were behaving as conservative constituents in the Newport River estuary, to explain the upper estuary peak and an inverse relation between bacteria numbers and salinity proceeding out into coastal water. However, this implies that the bacteria are only biologically active in the upper estuary, which was not the case for the Newport River and does not apply to our estuaries. There are indeed some changes in the bacteria, proceeding from upper estuarine waters to coastal and offshore waters. Earlier, Wright (1978) indicated that the 'specific activity', or per-cell heterotrophic activity of bacteria declined significantly in this transition. The present paper shows that the bacteria undergo a size shift from larger to smaller bacteria and a shift in the heterotrophic activity from larger to smaller bacteria in this same transition from upper estuary to coastal bacteria (Tables 3 and 4). It seems much more likely that such transitions are the result of the effects of the rate of supply of substrate and the rate at which the bacteria are being removed, rather than the same bacteria gradually making their way down the system and becoming inactive in the process. In other words, the bacteria in estuaries should be viewed as dynamic constituents, capable of much more variability and change than a simple mixing of water masses would predict.

One additional possibility for explaining the midestuarine peak involves exportation of bacteria from salt marshes and sediments as a consequence of tidal action. In another study (unpubl.) we were unable to find any significant differences in net amounts of bacteria entering and leaving a salt-marsh portion of the Essex estuary. Rublee et al. (in press) found that the net movement of bacteria in tidal exchange in the Rhode River estuary, MD, was in the direction of transport into the marshes. They concluded that marsh sediments do not appear to be a source of suspended bacteria for estuaries.

This paper has shown that the control of bacteria numbers and activity in a tidal estuary is a complex problem. Since the bacteria are so abundant in saltmarsh estuaries, understanding the factors that control them is essential in attempting to understand the fun- 
damental ecological systems of the estuary and their impact on coastal waters. In particular, more information is needed on the relationship between bacteria and naturally occurring substrate, on the sources and rates of supply of natural substrate in estuaries, and on the quantitative role of grazing. We will address a number of these questions in subsequent papers.

Acknowledgements. This material is based upon work supported by the National Science Foundation under Grant No. OCE-7925368.

\section{LITERATURE CITED}

Bell, C. R., Albright, L. J. (1981). Attached and free-floating bacteria in the Fraser River Estuary, British Columbia, Canada. Mar. Ecol. Prog. Ser. 6: 317-327

Bent, E. J., Goulder, R. (1981). Planktonic bacteria in the Humber Estuary; seasonal variation in population density and heterotrophic activity. Mar. Biol. 62: 35-45

Burney, C. M., Johnson, K. M., Sieburth, J. McN. (1981). Diel flux of dissolved carbohydrate in a salt marsh and a simulated estuarine ecosystem. Mar. Biol. 63: 175-187

Burney, C. M., Davis, P. G., Johnson, K. M., Sieburth, J. McN. (1982). Diel relationships of microbial trophic groups and in situ dissolved carbohydrate dynamics in the Caribbean Sea. Mar. Biol. 67: 311-322

Fenchel, T. (1980). Suspension feeding in cillated protozoa: feeding rates and their ecological significance. Microb. Ecol. 6: 13-25

Fuhrman, J. A., Ammerman, J. W., Azam, F. (1980). Bacterioplankton in the coastal euphotic zone: distribution, activity and possible relationships with phytoplankton. Mar. Biol. 60: 201-207

Fuhrman, J. A., Azam, F. (1980). Bacterioplankton secondary production estimates for coastal waters of British Columbia, Antarctica, and California. Appl. environ. Microbiol. 39: 1085-1095

Gak, D. S., Romanova, E. P., Romanenko, V. I., Sorokin, Y. I. (1972). Estimation of changes in number of bacteria in the isolated water samples. Ch. 5.2 In: Sorokin, Y. I., Kadota, H. (eds.) Microbial production and decomposition in fresh waters. Blackwell, Oxford, p. 77-82

Goulder, R., Blanchard, A. S., Sanderson, P. L., Wright, B. (1980). Relationships between heterotrophic bacteria and pollution in an industrialized estuary. Wat. Res. 14: 591-601

Haas, L. W., Webb, K. L. (1979). Nutritional mode of several non-pigmented microflagellates from the York River Estuary, Virginia. J. exp. mar. Biol. Ecol. 39: 125-134

Hågström, §., Larsson, U., Horstedt, P., Normark, S. (1979). Frequency of dividing cells, a new approach to the deter- mination of bacterial growth rates in aquatic environments. Appl. environ. Microbiol. 37: 805-812

Hobbie, J. E., Daley, R. J., Jasper, S. (1977). Use of Nuclepore filters for counting bacteria by fluorescent microscopy. Appl. environ. Microbiol. 33: 1225-1228

Larsson, U., Hågström, §. (1982). Fractionated phytoplankton primary production, exudate release and bacterial production in a Baltic eutrophication gradient. Mar. Biol. 67: $57-70$

Meyer-Reil, L.-A., Bölter, M., Liebezeit, G., Schramm, W. (1979). Short-term variations in microbiological and chemical parameters. Mar. Ecol. Prog. Ser. 1: 1-6

Morita, R. Y. (1980). Low Temperature, energy, survival, and time in microbial ecology. In: Schlessinger, D. (ed.) Microbiology 1980. Am. Soc. for Microbiology, Washington, p. 323-324

Palumbo, A. V., Ferguson, R. L. (1978). Distribution of suspended bacteria in the Newport River Estuary, North Carolina. Estuar. coast. Shelf Sci. 7: 521-529

Rublee, P. A., Merkel, S. M., Faust, M. A. (in press). Bacterial transport in the sediments of a temperature marsh. Estuar. coast. Shelf Sci.

Stevenson, H. L. (1978). A case for bacterial dormancy in aquatic systems. Microbial Ecol. 7: 127-133

Stevenson, H. L., Erkenbrecher, C. W. (1976). Activity of bacteria in the estuarine environment. In: Wiley, M. (ed.) Estuarine processes, Vol. 1, Uses, stresses and adaptions to the estuary. Academic Press, New York, p. 381-394

Turner, R. E. (1978). Community plankton respiration in a salt estuary and the importance of macrophytic leachates. Limnol. Oceanogr. 23: 442-451

Väätänen, P. (1980). Effects of environmental factors on microbial populations in brackish waters off the southern coast of Finland. Appl. environ. Microbiol. 40: 48-54

Valdés, M., Albright, L. J. (1981). Survival and heterotrophic activities of Fraser River and Strait of Georgia bacterioplankton within the Fraser River plume, Mar. Biol. 64: 231-241

Wilson, C. A., Stevenson, L. H. (1980). The dynamics of the bacterial population associated with a salt marsh. J. exp. mar. Biol. Ecol. 48: 123-138

Wright, R. T. (1978). Measurement and significance of specific activity in the heterotrophic bacteria of natural waters. Appl. environ. Microbiol. 36: 297-305

Wright, R. T., Coffin, R. B., Ersing, C. P., Pearson, D. (1982). Field and laboratory measurements of bivalve filtration of natural marine bacterioplankton. Limnol. Oceanogr. 27: 91-98

Wright, R. T. (in press). Dynamics of pools of dissolved organic carbon. In: Hobbie, J. E., Williams, P. J. (eds.) Microbial metabolism and the cycling of organic matter in the sea

Wright, R. T., Burnison, B. K. (1979). Heterotrophic activity measured with radiolabelled organic substrates. In: Costerton, J. W., Colwell, R. R. (eds.) Native aquatic bacteria: enumeration, activity and ecology. ASTM Special Publ. 695 